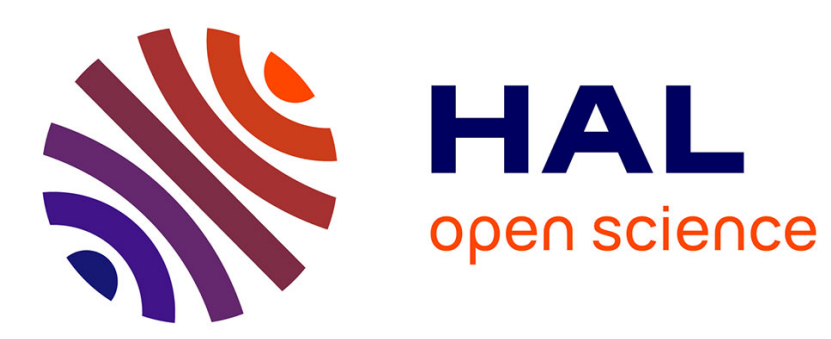

\title{
HIGH POWER EXCIMER LASERS FOR INDUSTRIAL APPLICATIONS
}

V. Borisov, O. Khristoforov, Yu. Kirykhin, S. Kuznetsov, Yu. Stepanov, A.

Vinokhodov

\section{- To cite this version:}

V. Borisov, O. Khristoforov, Yu. Kirykhin, S. Kuznetsov, Yu. Stepanov, et al.. HIGH POWER EXCIMER LASERS FOR INDUSTRIAL APPLICATIONS. Journal de Physique IV Proceedings, 1991, 01 (C7), pp.C7-589-C7-589. 10.1051/jp4:19917156 . jpa-00250831

\section{HAL Id: jpa-00250831 https://hal.science/jpa-00250831}

Submitted on 1 Jan 1991

HAL is a multi-disciplinary open access archive for the deposit and dissemination of scientific research documents, whether they are published or not. The documents may come from teaching and research institutions in France or abroad, or from public or private research centers.
L'archive ouverte pluridisciplinaire HAL, est destinée au dépôt et à la diffusion de documents scientifiques de niveau recherche, publiés ou non, émanant des établissements d'enseignement et de recherche français ou étrangers, des laboratoires publics ou privés. 


\section{HIGH POWER EXCIMER LASERS FOR INDUSTRIAL APPLICATIONS}

V.M. BORISOV, O.B. KHRISTOFOROV, Yu.B. KIRYKHIN, S.G. KUZNETSOV, Yu.Yu. STEPANOV and A.Yu. VINOKHODOV

The Troitsk Kurchatov Research Institute, Moscow Reg/742092, USSR

Pulse Laser System Laboratory has developed a wide research program of discharge pumped excimer lasers. The design and operation of high average power excimer laser systems is described. A large aperture $(10 \times 8 \mathrm{~cm}) \mathrm{XeCL}$ laser with UV preionization can produce $10 \mathrm{~J}$ per pulse at the repetition rates up to $100 \mathrm{~Hz}$. When aperture decreased, $\mathrm{XeCl}$ laser operates at repetition rates of $500 \mathrm{~Hz}$. Thus, we created several models of excimer lasers with different combinations of energy per pulse and repetition rate based an a single type of gas flow and power supply. The name of this models family is Gefest. The following table represents a summary of technical data of Gefest lasers.

$\begin{array}{lclc}\text { Name of base model } & \text { Gefest-1 } & \text { Gefest-3 } & \text { Gefest-10 } \\ \text { Wavelength } & 308 \mathrm{~nm} & 308 \mathrm{~nm} & 308 \mathrm{~nm} \\ \text { Energy per pulse (max) } & 1 \mathrm{~J} & 2.15 \mathrm{~J} & 10 \mathrm{~J} \\ \text { Repetition rate (max) } & 500 \mathrm{~Hz} & 300 \mathrm{~Hz} & 100 \mathrm{~Hz} \\ \text { Pulse duration } & 70 \mathrm{~ns} & 80 \mathrm{~ns} & 100 \mathrm{~ns} \\ \text { Beam crossection } & 1 \mathrm{cm \times 5} \mathrm{cm} & 2.8 \mathrm{~cm} \times 6 \mathrm{~cm} & 8 \mathrm{~cm} \times 10 \mathrm{~cm}\end{array}$

The Gefest lasers can be used as a prototype for the development of commercial high power excimer lasers for industrial applications.

In the second part of the report we shall discuss our results on excimer laser applications:

1. materials processing;

2. high temperature superconductor films;

3. the mobile universal lidar (aerosol fluctuation and ozone profiles, composition and quantity of air pollutants). 